\title{
Przygotować się do obrony przed bandami Mahometa, czyli Pana Michała algierskie przypadki
}

Mija trzydzieści lat od politycznego przełomu roku 1989 w Polsce i początku tzw. czarnej dekady w Algierii, która pogrążyła ten kraj w chaosie wojny domowej i skazała na międzynarodową izolację. Warto więc przypomnieć o tradycji polsko-algierskich relacji brutalnie przerwanych przez wyjazdy zagranicznych pracowników z Algierii na początku lat 90 . Wybory geopolityczne przywódców niepodległej Algierii po roku 1962 motywowane były ideami takimi jak panarabizm, antysyjonizm, arabski modernizm oraz islamski socjalizm. Otworzyło to drogę do współpracy gospodarczej, naukowej i handlowej z państwami bloku wschodniego oraz wymiany studentów i pracowników. Od lat 70. do Algierii wyjeżdżali tzw. kooperanci: inżynierowie, geolodzy, lekarze i nauczyciele zatrudnieni na podstawie kontraktu zawartego między stroną algierską a polskimi przedsiębiorstwami handlu zagranicznego. Symbolem współpracy między krajami są choćby rzeźby algierskich powstańców z wojny o niepodległość wykonane przez polskiego artystę Mariana Koniecznego. Trzy postaci: mudżahedina z partyzantki krajowej, żołnierza z oddziałów zagranicznych oraz członka Narodowej Armii Ludowej utworzonej po odzyskaniu niepodległości, pełnią straż u stóp trzech ogromnych betonowych liści palmowych górujących nad Algierem i tworzących Pomnik Chwały i Męczeństwa. Jak podaje Aleksandra Kasznik-Christian, autorka licznych prac o historii krajów Maghrebu, sama firma Polservice wysłała do Algierii ok. 1,5 tys. polskich pracowników naukowo-tech- 
nicznych, którzy nierzadko przybywali na miejsce z całymi rodzinami i tworzyli tymczasowe polonijne zbiorowości ${ }^{1}$.

O skali i znaczeniu polsko-arabskiej współpracy niech świadczy los Pawełka i Janeczki Chabrowiczów, rodzeństwa z powieści Skarby wydanej w 1988 r. przez Joannę Chmielewską. Gdy trafią przypadkowo na informację o tajemniczym skarbie ukrytym w Algierii, Pawełek i Janeczka zrobią wszystko, by załatwić ojcu kontrakt w Afryce Północnej i tym samym wyruszyć na poszukiwania. Przygotowanie wyjazdu do Algierii musiało być w ostatniej dekadzie PRL-u częścią swoistego know-how wśród polskich inżynierów i ich rodzin, skoro stało się elementem fabuły popularnego gatunku, jakim jest powieść przygodowa dla młodzieży, zwłaszcza w przypadku tak poczytnej autorki, jak Chmielewska. Przyjrzyjmy się, jak dziarsko do algierskiej przygody zabierają się syn i córka państwa Chabrowiczów:

Pawełek natychmiast przystąpił do rzeczy.

- No więc to się robi tak: trzeba zrobić fotokopie dyplomu ojca i uprawnień budowlanych. Przetłumaczyć to na francuski. Trzeba mu napisać życiorys i zaraz... czekaj...

Pośpiesznie wygrzebał z teczki zeszyt do fizyki, odwrócił go do góry nogami, otworzył na ostatniej stronie i dalej już czytał.

- Szczegółowy przebieg pracy zawodowej z podaniem wszystkiego, co zrobił, mają tam być różne kubatury, metry i w ogóle mnóstwo liczb. To też trzeba przetłumaczyć na francuski u tłumacza przysięgłego. Załączyć fotografię. Wszystko razem dać takiemu, co jedzie do Algierii, a tam on da takiemu, który znajdzie pracodawcę. Temu, co znajdzie pracodawcę, należy przywieźć prezent, bo to jest Arab. Od pracodawcy dostaje się kontrakt, idzie się z tym do Polservice'u i reszta już sama leci. Potem się jedzie do Algierii i można zabrać ze sobą całą rodzinę oraz meble, garnki, pralkę i samochód. Samochód koniecznie. Kropka.

- Skąd to wszystko wiesz? - spytała słuchająca Janeczka.

- Mojego jednego kumpla ciotecznego brata ojciec tak pojechał do Algierii, dopiero co. Wszystko wie. Ten kumpel dzwonił przy mnie do tego ciotecznego brata i on mu wszystko podyktował przez telefon. Przez tego ciotecznego brata można znaleźć takiego, co jedzie do Algierii, bo okazuje się, że tam jest mnóstwo ludzi od nas i bezustannie ktoś jeździ tam i z powrotem².

Pamięć o polskich pracownikach przechowała się także we współczesnej literaturze algierskiej. Jeden z najbardziej znanych pisarzy algierskich Mohammed Moulessehoul, publikujący pod pseudonimem Yasmina Khadra,

1 A. Kasznik-Christian, Algieria, Łódź 2006, s. 525-526.

2 J. Chmielewska, Skarby, Warszawa 1993 [1988], s. 20. 
wspomina w swojej autobiografii postać Madame Jarosz, polskiej nauczycielki języka francuskiego $\mathrm{z}$ algierskiej szkoły kadetów ${ }^{3}$. Sam przekonałem się w marcu 2018 roku o żywotności mitu polskiego pracownika w Algierii przy okazji konferencji literaturoznawczej w Beszszar. Gdy po zakończeniu sesji zwiedzaliśmy z koleżanką z Uniwersytetu Śląskiego oazę w Taghit na przedpolach Sahary, podbiegł do nas starszy mężczyzna z innej grupy i zaczął wypytywać: „You are from Poland? Do you know Bogdan Kisielewski from Muszyna? He is my friend". Po chwili rozmowy okazało się, że polski geodeta pracował $w$ algierskich kopalniach z naszym nowym znajomym. Więź przetrwała próbę czasu, zakończenie kontraktu i zmianę politycznych wiatrów: panowie wciąż byli w kontakcie, Algierczyk odwiedził przyjaciela w Polsce i czekał właśnie na jego wizytę w Algierii, która miała nastąpić w kwietniu 2018 roku. Na znak przyjaźni polsko-algierskiej otrzymaliśmy od Aziza 20 tys. dinarów z poleceniem wypicia kawy za jego zdrowie oraz niebieski pustynny szal do ochrony przed maghrebskim słońcem. Hasło "Polska” wywołało podobny entuzjazm u przewodnika, który oprowadzał nas po ksarze, pustynnym osiedlu-fortecy z gliny w Kenadsie. Nie mógł nachwalić się polskich pracowników, którzy „pomagali budować niepodległą Algierię”.

Polska obecność w Algierii nie ogranicza się jednak tylko do pamięci o kooperantach i ich rodzinach ${ }^{4}$. Polscy emigranci byli obecni w całym Maghrebie już w XIX wieku i towarzyszyli francuskiemu podbojowi tej części świata. Uchodźcy polistopadowi - bądź to jako członkowie Legii Cudzoziemskiej, bądź emigranci cywilni - tworzyli polskie organizacje w Algierze, Konstantynie, Bône (dzisiejsza Annaba) i Philippeville (Sakikda). Polskie oddziały walczyły po stronie francuskich kolonizatorów, choćby z emirem Abd el-Kaderem, uznawanym dziś za jednego z pierwszych algierskich bohaterów narodowych. Józef Poniatowski, uczestnik powstania listopadowego i wojny kolonialnej w Algierii, naturalny syn księcia Józefa Poniatowskiego, pochowany jest na cmentarzu w Oranie. Służba uchodźców w Legii Cudzoziemskiej przebiegała pod znakiem dylematu między dążeniem do zapewnienia polskim oddziałom trwałej struktury $w$ ramach francuskiej armii a sympatią dla Arabów walczących o zachowanie niepodległości. Kontakty z muzułmanami przyczyniały się do powstania memoriałów, w których zabierano głos w sprawie podboju kolonialnego. Redagowali je m.in. Alexandre Walewski, syn cesarza Francuzów Napoleona I i Marii Walewskiej, Józef Tański, polsko-francuski oficer i dziennikarz czy Henryk Dembowski, uczestnik misji wojskowej w Egipcie.

3 Y. Khadra, L'écrivain, Paryż 2001, s. 201.

4 A. Kasznik-Christian Algieria, s. 501 i n. 
Nie sposób pominąć cywilnych uchodźców zaangażowanych we francuskie przedsięwzięcie kolonialne lub pracę naukową. Teofil Mirski, właściciel terenów nadanych mu przez administrację kolonialną, gospodarował swoim majątkiem, utrzymując dobre stosunki z ludnością arabską. Mirski zdecydował się na wyjazd do Algierii ze względu na złe stosunki z emigracją polską w Paryżu. Koncesja otrzymana od Francuzów pozwoliła mu założyć w miejscowości Rassauta fermę o powierzchni 4300 ha ${ }^{5}$. Edward Lewandowski, postyczniowy emigrant osiadły w Algierze, założył pierwszą w Algierii klinikę hydroterapii. Kalasanty Motyliński, urodzony już w Algierii francuski orientalista polskiego pochodzenia, badał języki berberyjskie z regionu Mzabu.

Nowy etap $\mathrm{w}$ relacjach polsko-algierskich rozpoczął się $\mathrm{w}$ związku z demontażem systemu kolonialnego po drugiej wojnie światowej. Jeszcze przed ogłoszeniem niepodległości Algierii, PRL nawiązała stosunki dyplomatyczne z Rządem Tymczasowym Republiki Algierskiej. Ten nowy rozdział pisali m.in. kooperanci i specjaliści. Środowisko polonijne dokumentowało swoją działalność na łamach dwóch periodyków: „Notatnika Orańskiego” oraz „Mozaiki Algierskiej”. Pobyt rodzin kooperantów gwałtownie przerwały zmiany geopolityczne w końcówce lat 80.: transformacja ustrojowa w Polsce i początki wojny domowej w Algierii ${ }^{6}$.

Jednym z kooperantów był Michał Christian, urodzony w 1942 roku inżynier, absolwent Politechniki Krakowskiej, który w drugiej połowie lat 80 . pracował w Annabie i Algierze jako specjalista od naprawy maszyn budowlanych i samochodów. Doświadczenia z pobytu w Algierii zebrał w książce Muzutmanie, islam i ja. Wspomnienia kooperanta z Algierii (1986-1990), wydanej w 2007 roku. Choć opatrzona jest numerem ISBN, nie zawiera żadnej informacji o wydawnictwie, co pozwala przypuszczać, że autor opublikował ją na własny koszt. O ile głównym powodem wyjazdu Christiana była chęć dołączenia do żony - Aleksandry Kasznik-Christian, profesor historii z Uniwersytetu Jagiellońskiego, uczestniczki wielu stypendiów naukowych w Afryce Północnej - o tyle impulsem do spisania wspomnień z Algierii i re-

5 B. Troński, Algierskie osobliwości, Poznań 1984, s. 202.

6 Nie mogę nie wspomnieć w tym miejscu o jednym z tych zbiegów okoliczności, które urozmaicają pracę literaturoznawcy spędzającego dzień w bibliotece. W cytowanej już reporterskiej książce Bronisław Troński wymienia... Jędrzeja Pawlickiego, architekta budującego w latach 80. XX wieku meczet i centrum kulturalne w Batnie. Troński pisze o nim także w korespondencji dla „Dziennika Łódzkiego”: „W Batnie popularny jest polski architekt z Gdańska, Jędrzej Pawlicki. Przy ulicy Sidi Hani budowany jest meczet według jego projektu. Po raz pierwszy zastosował on w dekoracji meczetu elementy bogatej regionalnej sztuki. Zaakceptowany został przez władze miejskie jego projekt budowy tak zwanego «Centrum Islamistycznego» z wielkim meczetem, biblioteką, salą odczytową, księgarnią wydawnictw arabskich i dzieł koranicznych" [B. Troński, Nasi w Algierii, „Dziennik Łódzki”, 13-15.11.1981, s. 6]. 
fleksji o kulturze arabsko-muzułmańskiej okazały się zamach terrorystyczny na Nowy Jork z 11 września 2001 roku oraz książki Oriany Fallaci: Siła rozumu, Wściekłość i duma oraz Wywiad z samym sobq. Apokalipsa. Na czwartej stronie okładki autor sam zachęca czytelnika do sięgnięcia po książkę, twierdząc, że przebijają z niej rzadko dziś spotykane „optymizm, altruizm i wolterowska ironia".

Wspomnień Michała Christiana nie da się przypisać do jednego z gatunków prozy autobiograficznej. Otwiera je dedykacja: „W hołdzie Orianie Fallaci", po niej zaś autor zamieszcza krótką notatkę zatytułowaną Zamiast wstępu:

Zastanawiam się jak to nazwać co napisałem? Literatura faktu, pamiętnik, proza, satyra? Rozprawki naukowe, historyczne, filozoficzne? Wykłady z islamu, akt oskarżenia? Wszystkiego po trochu. Starałem się nie być zbyt poważny ani broń Boże zbyt nudny. Podobno czyta się dobrze. Zachęcam Czytelników i życzę smacznej lektury ${ }^{7}$.

Już z tej wstępnej deklaracji przebija świadomość niemożliwości gatunkowego określenia tekstu, którego autor, powołując się na klasyków pisarstwa antyreligijnego - z iście Wolterowską ironią - wzywa Boga na świadka własnych zdolności literackich. Czytelnik skuszony spisanym na gorąco świadectwem „polskiego życia” w Algierii u progu wojny domowej i narodzin islamskiego terroryzmu musi się jednak uzbroić w cierpliwość: zanim dotrze do lektury głównej części wspomnień, przyjdzie mu jeszcze zmierzyć się ze słynną Desideratą, zamieszczoną po tym krótkim wstępie i opatrzoną adnotacją, że "była i nadal jest śpiewana w Piwnicy pod Baranami w Krakowie". Ten heterogeniczny wstęp należy uznać za świadomą strategię autora, który będzie przedstawiał się czytelnikowi jako człowiek nauki i kultury, racjonalny wolnomyśliciel $\mathrm{z}$ artystowskiego dużego miasta, ateizujący sceptyk z Europy wodzący na pokuszenie zacofanych i leniwych muzułmanów.

Główny tekst podzielony jest na cztery części. W dwóch pierwszych Michał Christian zamieszcza obszerne skróty ze stu pięćdziesięciu listów wysłanych do żony. Zapisane kursywą listy przeplatane są komentarzami autora, stanowiącymi główną część wspomnień. Ten swoisty pamiętnik polskiego kooperanta zamyka tzw. Opowieść noworoczna, czyli spisany i uzupełniony po latach wykład o Mahomecie i początkach islamu, który autor miał wygłosić polskim znajomym w dniu Nowego Roku 1989 w Algierze. Jak sam zaznacza, części III i IV zostały zredagowane po 11 września 2001 roku.

7 M. Christian, Muzutmanie, islam i ja. Wspomnienia kooperanta z Algierii (1986-1990), s. 7. Kolejne cytaty lokalizuję w tekście głównym, sygnując je literą M. Pisownia we wszystkich cytatach $\mathrm{z}$ analizowanej książki oryginalna. 
Wielość i różnorodność tematów poruszonych w części III pozwalają domyślać się, że intencja autora znacznie przekracza ramy czasowo-przestrzenne zakreślone $\mathrm{w}$ podtytule książki (Wspomnienia kooperanta z Algierii 1986-1990). Ze względu na bogactwo treści, niespotykane nawet $\mathrm{w}$ tak pojemnym gatunku, jak literatura diarystyczna, warto tu wymienić wszystkie poruszone wątki i problemy: rozwój islamu; Bracia Muzułmanie i terroryzm; kobiety $\mathrm{w}$ islamie; brak wolności religijnej $\mathrm{w}$ państwach muzułmańskich; chrześcijanie, żydzi oraz wyznawcy innych religii w islamie; kalendarz muzułmański; filary wiary; hadisy, sunna i szariat; apostazja; upadek cywilizacyjny; pojęcie rozumu i inteligencji w katolicyzmie i islamie; emigranci muzułmańscy w krajach europejskich; kalendarium ataków terrorystycznych od 1972 do 2005; historia niepodległej Algierii; kalendarium wydarzeń w świecie islamu od 1978. Użycie w stosunku do tej listy słowa "problemy” wydaje się nadużyciem: istotnie, nic tu nie jest sproblematyzowane, a na czytelnika nie czeka żadne zaskoczenie, chyba że uznać za takowe śmiałą i odważną tezę historiozoficzną o upadku cywilizacji Persji, Indii i Egiptu wskutek podbojów arabskich i ich nieoczekiwanym wpływie na podbój kosmosu w XX wieku, zgodnie z którą, "[g]dyby nie najazdy prymitywnych plemion arabskich, te cywilizacje dalej by się rozwijały [...]. Być może już dawno zasielibyśmy jakąś planetę w kosmosie" [M, s. 286]. Część IV stanowią tzw. świadectwa intelektualistów z krajów muzułmańskich lub Europejczyków pracujących w tych krajach, czyli omówienia materiałów prasowych z "Polityki”, "Gazety Wyborczej" oraz portalu eurojihad.org.

Te swoiste "rozprawki naukowe, historyczne, filozoficzne" nie świadczą być może o wybitnych talentach argumentacyjnych autora, ale nie sposób odmówić mu daru opowiadania interesujących historii. Choć wspomnienia Michała Christiana nie przeszły przez żadne redakcyjne sito, z I i II części książki wyłania się żywy i zajmujący obraz społeczności polskich kooperantów w Algierii i ich kontaktów z muzułmanami. Listy Christiana do żony były pisane $\mathrm{w}$ niezwykle interesującym momencie historycznym: w czasie kryzysu gospodarczego i politycznego, który miał doprowadzić do pierwszych w historii niepodległej Algierii wolnych wyborów parlamentarnych i zwycięstwa w nich partii islamistów - Islamskiego Frontu Ocalenia (FIS - Front islamique du salut). Kreśląc portret jednego z polskich inżynierów zatrudnionych od wielu lat $\mathrm{w}$ firmie Edemines $\mathrm{w}$ Algierze, autor zauważa: „Zakochany w Algierii, ale chyba w tej, która już mija” [M, s. 88].

Christian zdradza umiejętność budowania napięcia narracyjnego, choćby w epizodzie z niesprawnymi cysternami. Problem rozwiązuje na zasadzie dedukcji, przypominając sobie podobną usterkę z czasów pracy w krakowskiej zajezdni autobusów: zbiornik paliwa zatkany był szmatą służącą mechani- 
kom do mycia rąk. Jednak w wartkiej opowieści Christiana usunięcie awarii staje się walką o pozycję polskiego mechanika:

Każę mu szukać szmaty pływającej na dnie. Raszid jest skonfundowany. Obok zbiera się grupka mechaników. Mój autorytet wisi na szali. Zagrałem pokerowo. Raszid stawia opór. Michel, mówi, ty masz rentgena w oczach czy co? Potem pogadamy. Szukaj. Napięcie wzrasta. Raszid wpycha rękę, aż poza łokieć. Grzebie. Jest, wrzeszczy, i wyciąga kawał niebieskiej szmaty. Skąd wiedziałeś pyta? Potem ci powiem. Zanieś to do Mżduba i opowiedz co tu się działo. Berliet naprawiony. Wygrałem bitwę o cysternę i o swój autorytet [M, s. 106].

Życie polskiego inżyniera w Algierii pełne jest więc przygód. Kolejna $\mathrm{z}$ nich to udział $\mathrm{w}$ polowaniu na dziki $\mathrm{z}$ nagonką. Schowany $\mathrm{w}$ krzakach z bułgarskim towarzyszem Valentinem Christian przygląda się polowaniu i przeżywa moment grozy, gdy spłoszony dzik pędzi na parę przyjaciół: "Gdy dzik był już bardzo blisko z całym rozmachem rzucam toporkiem. Wściekłe bydle goniło jak strzała. Nie miałem szans. Ale przynajmniej wziąłem czynnie udział $\mathrm{w}$ polowaniu. To zwierzę uciekło. Uratował się z pogromu" [M, s. 149]. Nie sposób odmówić autorowi pewnej wrażliwości na los zwierząt. W dalszej części opowieści o uciekających dzikach powie wprost: „Uratowały się z rzezi” [M, s. 150] ${ }^{8}$.

Dynamiczna i realistyczna narracja podporządkowana została jednak nadrzędnemu celowi Christiana, czyli krytyce islamu rozumianego jako jednolity i niezmienny $\mathrm{w}$ czasie blok kulturowo-religijny. Nie po to jest się w końcu myślącym bez alienacji ateistą i bywalcem Piwnicy pod Baranami, by milczeć na widok pogrążonych w odmętach zabobonu Arabów. I tak epizod polowania staje się dla autora okazją, by podzielić się z czytelnikami wiedzą tajemną, dostępną nielicznym, którzy zdobyli się na trud studiowania islamu i muzułmańskich obyczajów:

Z zabudowań gospodarczych wyprowadzono kilka psów, rozpoznałem dwa wyżły, spaniela i setera, pozostałe to jakieś mieszańce. Psy były zadbane, radosne i uśmiechnięte. Było to dziwne, bo jak wiem Mahomet nie lubił psów, stąd i wśród Arabów traktowane są one pogardliwie. A dlaczego Mahomet nie lubił psów? Wierni mówią, że kiedyś pies ugryzł Mahometa w łydkę. Jak tak można. Świętego człowieka ugryźć w łydkę? Ale ja wiem co innego. Podczas nocnych napadów na różne osady i oazy, psy zdradzały obecność rabusiów. Ludność miała czas, by przygotować się do obrony przed bandami Mahometa [M, s. 148].

8 O wyprawach na polowanie na dziki wspomina także w swojej książce inny z kooperantów, geolog z Poznania, Andrzej Pawuła. Zob. A. Pawuła, Algierskie reminiscencje, Poznań 2018, s. 60-61. 
Powyższy fragment zdradza ulubioną metodę argumentacyjną inżyniera Christiana: byłem na miejscu, widziałem, a w dodatku czytałem, swoje wiem, więc piszę. Niezrażony tym, że wnioski dotyczące przedstawicieli zróżnicowanego kręgu kulturowego rozciągającego się od Maroka po Indonezję wyciąga na podstawie czteroletniego pobytu w Afryce Północnej i dostępnej wówczas listy lektur, autor podkreśla wielokrotnie "naukowy” charakter swojego przedsięwzięcia: "Muszę podciągnąć się z islamu”, pisze do żony z prośbą o książki [M, s. 48]. Lektury i obserwacje utwierdzają Christiana $\mathrm{w}$ demaskatorskiej misji, a quasi religijny zapał sprawia, że z iście krakowską, artystowską nonszalancją podchodzi do takich elementów warsztatu naukowego, jak kwerenda i zasada falsyfikacji, nie wspominając o interpunkcji. „Ale nie wiem co w końcu napisał i nie muszę wiedzieć”, odnotowuje na temat prac jednego z arabistów [M. s. 241]. Uroczo niewinny jest zabieg stosowany przez tego „świeżo upieczonego" adepta islamologii, który własną jaźń bierze za całość dostępnej ludzkości na dany temat wiedzy: „Warty omówienia jest punkt pierwszy [edukacja dzieci w krajach muzułmańskich], ponieważ żaden $\mathrm{z}$ arabistów nad nim nie zastanawiał się porządnie, a nasza wiedza na ten temat jest nikła" [M, s. 284]. I choć zastosowana $\mathrm{w}$ tym wywodzie synekdocha zdaje się - $\mathrm{w}$ intencji autorskiej - odsyłać do wysokiego kwantyfikatora, jak czytelnicy w Polsce, w Europie lub na Zachodzie, nie da się ukryć, że „nasza wiedza” jest tworzona i rozpowszechniana przez ściśle określoną grupę epigonów Oriany Fallaci.

Szok związany z zamachami z 11 września sprawił, że jej reprezentanci zrezygnowali z prób opisu złożonej rzeczywistości świata na początku XXI wieku na rzecz esencjonalistycznej, huntigtonowskiej wizji zderzenia cywilizacji. Zgodnie z nią Christian odwołuje się do książki Craiga Winna:

po ataku Attty i jego kolegów na wieże WTC, milioner amerykański Craig Winn postanowił zrozumieć istotę islamu. [...] Powstało dzieło pod tytułem Prorok apokalipsy. Wnioski autora są bulwersujące, że Koran Mahometa i Mein Kampf Hitlera są ideologicznie bardzo do siebie podobne. W języku francuskim książka ta jest do nabycia w AMAZON [M, s. 243].

Problem w tym, że nie da się zrozumieć rzekomej istoty islamu, bo taka nie istnieje, tak, jak nie istnieje mityczna esencja Zachodu. Zjawiska religijne i kulturowe rozwijają się w czasie. Przypisując im niezmienne cechy i odbierając prawo do wewnętrznej ewolucji, Christian wykazuje się złą wolą. Popełniając zaś błąd w zapisie przywódcy terrorystów, wpisuje się awansem na długą listę polskich samozwańczych ekspertów od zamachów lotniczych. Użycie wreszcie argumentum ad Hitlerum zamyka dalszą dyskusję. 
Poglądy autora na status tekstów literackich są niemniej kontrowersyjne. Gdy Christian krytykuje algierskie prawodawstwo rodzinne $z$ lat 70. i 80. XX wieku, przywołuje powieść Yasminy Khadry Jaskółki z Kabulu o Afganistanie pod rządami talibów. Wypada tu zauważyć, że dystans czasowy i przestrzenny między Algierem w 1980 roku a Kabulem w roku 2000 jest znaczny. Mimo to autor krytykuje wypowiedzi wychwalające szariat w następujący sposób: „Proponuję porównać tę apologię, ze stanem faktycznym opisanym w smutnej powieści Yasmina Khadra, Jaskółki z Kabulu" [M, s. 307]. Jeśli coś dzieli więc ze wspomnianą powieścią status fikcji, są to bez wątpienia pseudonaukowe i orientalistyczne poglądy autora.

Jak zauważa Monika Bobako, poglądy Oriany Fallaci na islam i kulturę arabsko-muzułmańską kierują się logiką zemsty i wyrażane są w formie kazań9. Kluczowym elementem tego wyznania wiary jest pogarda wyrażana $\mathrm{w}$ stosunku do wszystkiego, co związane $\mathrm{z}$ islamem i muzułmanami. Wybierając Fallaci na patronkę swojej antymuzułmańskiej homilii, Christian przejmuje również jej strategię. Pogarda przebrana w szaty europejskiego, oświeconego rozumu wybrzmiewa donośnie w wielu fragmentach książki krakowskiego inżyniera. Nie waha się nazwać algierskiej kobiety "głupią babą" [M, s. 114], współczesne obyczaje muzułmanów określa mianem „patologicznej manii religijnej" [M, s. 217], poglądy arabistów nazywających islam religią pokoju kwituje jednym zdaniem: „Jest to oczywista nieprawda i kabaretowa bzdura" [M, s. 269].

Tropiąc rzekome wewnętrzne sprzeczności muzułmańskiej teologii, Christian nie problematyzuje własnej „metody badawczej”. Wystarcza mu odwołanie do autorytetu Fallaci, odważnej intelektualistki, która chce wstrząsnąć Europejczykami w obliczu muzułmańskich jeźdźców Apokalipsy nadciągających masowo na pontonach.

Uderzające jest to, że w narracji Fallaci logika rytualnej zemsty zdaje się całkowicie przesłaniać kwestię, czy taki sposób traktowania ludzi kojarzonych $\mathrm{z}$ islamem jest do pogodzenia z europejskimi zasadami prawnymi i standardami etycznymi. Fakt ten ujawnia paradoks, a może zwykłą sprzeczność, tkwiącą w myśleniu dziennikarki. Polega on na tym, iż z jednej strony zadeklarowanym celem Fallaci jest obrona Europy, jej kultury i wartości przed islamem. Z drugiej strony okazuje się, że już sam wybrany przez nią sposób obrony tych wartości można uznać za ich pogwałcenie ${ }^{10}$.

Islamofobiczna ideologia zbudowana jest więc na wizji, która udaje wiedzę. Odwaga pogardzania nie wspiera się na naukowych dowodach, ale emo-

9 M. Bobako, Islamofobia jako technologia władzy, Kraków 2017, s. 54 i n.

10 Tamże, s. 57-58. 
cjonalnym szantażu i osobistych obsesjach „kapłanów” tej świeckiej religii. Christian z lubością cytuje Wikipedię jako jedno ze swoich źródeł, a znajomość Koranu potwierdza następującym zdaniem: „Mam cały Koran zeskanowany i przerzucony do Word'a. Poszukiwanie dowolnego słowa w Koranie jest bardzo proste i automatyczne" [M, s. 269]. W ten właśnie sposób autor książki jednym zdaniem, z właściwą sobie inżynierską - by nie powiedzieć aptekarską, godną pana Homais'ego - precyzją podważa wielowiekową tradycję egzegezy Koranu. Jeśli zaś metoda interpretacyjna oparta na skrócie klawiszowym CTRL+F prowadzi nieuchronnie do wykrycia sprzeczności tekstu, tym gorzej dla niego: „Czy jest normalną rzeczą, by księga objawiona przez Boga zawierała tak wiele poważnych sprzeczności?" [M, s. 338]. Paradoksy, antytezy i wewnętrzne sprzeczności są nieodłączną cechą każdego tekstu uznawanego przez jakąś część ludzkości za święty. Uczą się o tym na pierwszym roku studenci kierunków filologicznych, czytający Bliznę Odyseusza Auerbacha, w której niemiecki badacz porównuje styl homerycki ze stylem biblijnym: „W opowieści biblijne wciela się nauka i obietnica, są one z nimi stopione nierozłącznie; właśnie dlatego opowieści te są tak mroczne i pełne głębi, zawierają drugi, ukryty sens"11. Mimo doktrynalnych różnic między chrześcijaństwem a islamem oraz różnych kontekstów powstania ksiąg biblijnych i Koranu zdanie to można odnieść również do lektury tego ostatniego. Literalne odczytanie świętej księgi muzułmanów przez oświeceniowego krytyka jest rewersem jej dosłownej interpretacji przez religijnych fundamentalistów: obie grupy wykluczają ze spotkania z tekstem dramatyzm ludzkiego życia. Algierski filozof i islamolog Mohammed Arkoun rozwijał teorię wielopiętrowego czytania i interpretowania Koranu: od poziomu transcendentnego Słowa Bożego, przez dyskurs koraniczny, czyli słowa wypowiedziane w konkretnym miejscu i czasie przez Mahometa, dalej przez ich kanoniczną redakcję za czasów trzeciego kalifa Usmana, aż po późniejsze zbiory komentarzy ${ }^{12}$. Sam termin "Koran” odsyła więc do zróżnicowanej rzeczywistości, której nie da się badać tymi samymi narzędziami. Idea Słowa Bożego, niedostępnego bezpośrednio ludzkiemu poznaniu - znanego chrześcijanom jako Logos z Ewangelii Jana - wyrażona jest w Koranie w wersecie 27 sury Lokman: „Zaprawdę, jeśliby wszystkie drzewa na ziemi były piórami i jeśliby było morze, któremu pomogłoby jeszcze siedem mórz - to nie wyczerpałyby się słowa Boga" ${ }^{13}$. Objawienie przekazane za pośrednictwem bożego pośred-

11 E. Auerbach, Blizna Odyseusza, w: tegoż, Mimesis. Rzeczywistość przedstawiona w literaturze Zachodu, przeł. Z. Żabicki, Warszawa 2004, s. 40.

12 M. Arkoun, Lectures du Coran, Paryż 2016, s. 14-15.

13 Koran, przeł. J. Bielawski, Warszawa 2016, s. 495. 
nika jest tylko fragmentem nieskończonego Słowa. Skoro w wielu miejscach muzułmańskiego świata przeważają tendencje fundamentalistyczne, prowadzące do przemocy religijnej, nie warto pomijać milczeniem wysiłku islamskiej teologii zmierzającego do wyodrębnienia transcendentnego poziomu objawienia, opierającego się wszelkim próbom zawłaszczenia.

Arkoun nie jest jedynym współczesnym teologiem pracującym nad odnową muzułmańskiego dyskursu religijnego. Zmarły w 2016 roku algierski religioznawca Malek Chebel promował w swoich pracach ideę „islamu Oświecenia", podkreślając, że religia i oświeceniowa krytyka nie są skazane na odwieczny antagonizm ${ }^{14}$. Francusko-tunezyjski pisarz i wykładowca akademicki Abdelwahab Meddeb prowadził w stacji France Culture znaną audycję radiową Cultures d'islam i przedstawiał szerokiemu gronu odbiorców islam jako ścieżkę duchową. Jego ostatnia praca to zbiór krótkich próz poetyckich poświęconych największym mistrzom sufizmu ${ }^{15}$. Z kolei tunezyjska islamolożka Olfa Youssef wykorzystuje narzędzia językoznawstwa i psychoanalizy w swoich pracach dotyczących interpretacji Koranu ${ }^{16}$. Promuje także dialogiczne podejście do religii, $\mathrm{w}$ ramach którego kontrowersje związane z doktryną muzułmańską nie są rozstrzygane autorytatywnie przez reprezentantów władzy religijnej, lecz poddawane debacie umożliwiającej każdemu wierzącemu wybranie własnego stanowiska ${ }^{17}$.

Uprawiając „oświeceniową" krytykę islamu, Michał Christian nie dostrzega - lub nie chce dostrzegać - że doktryna muzułmańska dopuszcza również możliwość zniesienia lub uchylenia jednego wersetu Koranu przez inny, późniejszy. Mówi o tym werset 206 sury Krowy: „Kiedy znosimy jakiś znak albo skazujemy go na zapomnienie, przynosimy lepszy od niego lub jemu podobny. Czy ty nie wiesz, że Bóg jest nad każdą rzeczą wszechwładny?!"18. Sprzeczności są wpisane w wewnętrzną dynamikę tekstu, zwłaszcza jeśli weźmiemy pod uwagę spory teologów muzułmańskich o naturę Koranu. Poszczególne kierunki filozofii arabskiej przez wieki różnie odnosiły się do możliwości zniesienia wersetu. W doktrynie mutazylickiej, mniejszościowej w obrębie islamu sunnickiego i rozwijającej się $\mathrm{w}$ VIII wieku ${ }^{19}$, zniesienie lub uchylenie wersetu nie było problemem

\footnotetext{
14 Zob. M. Chebel, Manifeste pour un islam des Lumières, Paryż 2011.

15 Zob. A. Meddeb, Instants soufis, Paryż 2015.

16 Zob. O. Youssef, Le Coran au risque de la psychanalyse, Paryż 2007. Książka ukazała się w kolekcji „L'islam des Lumières”.

17 Zob. O. Youssef, Sept controverses en islam. Parlons-en!, Tunis 2016.

18 Koran, s. 22.

19 J. Danecki, Kultura islamu. Stownik, Warszawa 1997, s. 145.
} 
z punktu widzenia teologicznego. Mutazylici uznawali, że elementy prawa objawionego $\mathrm{w}$ Koranie mogą się zmieniać $\mathrm{w}$ zależności od epoki, ponieważ święta księga została stworzona i objawiona w czasie. Uznanie dogmatu Koranu przedwiecznego byłoby dla nich równoważne z chrześcijańskim dogmatem Wcielenia. Afirmacja Koranu stworzonego wynika w mutazylizmie z koncepcji jedności Boga jako bytu oddzielonego od świata ludzi, niepodlegającego określeniom odnoszącym się do stworzeń, koncepcji statycznej, negującej jakąkolwiek możliwość ujrzenia Jedynego ${ }^{20}$. Odwieczny Koran przeczyłby monoteizmowi jako podstawie wiary muzułmańskiej ${ }^{21}$. W doktrynie teologicznej aszarytów z kolei, najbardziej rozpowszechnionej w sunnizmie i wywodzącej się z X wieku, pogląd o czasowości i zmienności prawa objawionego w Koranie był problematyczny ze względu na przekonanie o ostatecznym zamknięciu objawienia po śmierci Mahometa ${ }^{22}$. Al-Aszari, którego imię dało nazwę temu nurtowi teologicznemu, uważał Koran za odwieczny, a nie za stworzony ${ }^{23}$.

„Polski Wolter" jest jednak konsekwentnie odporny na dynamiczny i diachroniczny wymiar zjawisk kulturowych i religijnych. W pasji upraszczania rzeczywistości i sprowadzania paradoksów do rangi pospolitej bzdury sięga właśnie po porównanie do średniowiecza: „Śmiech mnie ogarnia: czy islam może być nowoczesny, skoro wywodzi się on z mrocznego średniowiecza?" [M, s. 318]. Walcząc z mniej lub bardziej uciążliwymi zwyczajami religijnymi i zwykłymi absurdami życia codziennego w Algierii w drugiej połowie lat 80. XX wieku, krakowski inżynier sam powiela klisze dotyczące wieków średnich, epoki zróżnicowanej, obejmującej wiele zjawisk, rozciągającej się na wiele wieków. Zła wola polemisty czy ignorancja?

Wystarczy jednak, że jakiś element średniowiecznej tradycji pochodzi z Europy, by przytoczyć go jako argument potwierdzający muzułmańskie zacofanie cywilizacyjne. Książkę Christiana zamykają tablice historyczne skonstruowane według subiektywnych kryteriów autora. Przedstawiają rozwój judaizmu, islamu i chrześcijaństwa. Jest to jednak rozwój pozorny. Historia według Christiana zmierza do z góry wyznaczonego celu, jakim jest konfrontacja cywilizowanej Europy z islamskim zagrożeniem. Ważnym składnikiem europejskiego dziedzictwa jest zaś duchowość Benedykta z Nursji, oparta na haśle „Módl się i pracuj”. Christian wymienia nauki Benedykta między uznaniem chrześcijaństwa za religię państwową przez Konstantyna a początkiem

\footnotetext{
20 H. Corbin, Historia filozofii muzutmańskiej, przeł. K. Pachniak, Warszawa 2009, s. 102-103.

21 J. Danecki, Arabowie, Warszawa 2015, s. 291.

22 Dictionnaire du Coran, red. M.A. Amir-Moezzi, Paryż 2007, s. 14.

23 J. Danecki, Arabowie, s. 293.
} 
krucjat. Benedykt jest mu potrzebny do potwierdzenia tezy o etyce pracy wykształconej w ramach europejskiego chrześcijaństwa - w przeciwieństwie do gnuśnych Arabów zdających się na fatum, czyli łaskę Allaha.

Połączenie selektywnej krytyki islamu z pogardzającym duchowością i myśleniem religijnym rozumem nie zostawia miejsca na zrozumienie zjawiska religijności jako takiej. Autor wspomnień z Algierii nie dostrzega faktu, że zarówno chrześcijaństwo Benedykta, jak i islam zwykłych Algierczyków są propozycjami różnych form duchowości. Nie może zresztą tego zauważyć, gdyż swoją tożsamość buduje na pseudonaukowym światopoglądzie $\mathrm{i}$ ateistycznej redukcji. Tymczasem $\mathrm{w}$ regule Benedykta praca stanowi jeden z elementów duchowej ścieżki, nie mniej i nie bardziej ważny niż pozostałe, nie jest związana z optymalizacją zadań i praktycznym zyskiem, choć w średniowiecznej Europie klasztory odgrywały ważną rolę w gospodarce. „Praca, modlitwa, wypoczynek, lektura - a wszystko to w poczuciu, że Bóg na nas patrzy, że żyjemy w Bożej obecności, że to nie my zbudowaliśmy dom Bogu, ale mieszkamy u Niego, jesteśmy u Boga, ubodzy", pisze o benedyktyńskiej regule Michał Zioło, polski mnich z zakonu trapistów ${ }^{24}$. Etyka Benedykta z Nursji jest etyką wyzbycia się kontroli, chęci panowania, podporządkowania sobie świata i opisania go, do czego zmierza z kolei inkwizytorska pasja epigonów Oriany Fallaci.

Tezy Michała Christiana domagają się także postkolonialnej dekonstrukcji, tak jak widział ją Edward Said. Autor słynnego Orientalizmu opisał intelektualistów i pisarzy, dla których islam od początku skazany jest na swoje ułomności, i którzy opierają się wszelkim islamskim próbom zreformowania religii muzułmańskiej ${ }^{25}$. Esencjonalistyczna odmienność islamu usprawiedliwia w ich oczach europejskie poczucie wyższości i wolę rządzenia. Poglądy Michała Christiana na islam i kulturę arabsko-muzułmańską w pełni wyczerpują saidowską definicję orientalizmu, są subiektywną wizją przebraną za wiedzę. Uważam, że analizę tę warto uzupełnić o jeszcze jeden czynnik postsekularną rewizję poglądów Christiana na islam. Postsekularyzm rozumiem zaś jako szansę i ryzyko otwarcia się humanistyki na sprawy ducha. Przedrostek "post" nie oznacza tu zwykłego następstwa w czasie i przejścia do kolejnej fazy rozwoju nauki i cywilizacji, ale przesunięcie w ramach obowiązującego paradygmatu. Ostatecznie linia podziału nie przebiega między oświeconym i liberalnym Zachodem a konserwatywnym i barbarzyńskim Orientem, ale w poprzek tych - jakże często wyobrażonych - wspólnot. Wydarzenia ostatnich trzech dekad udowodniły aż nadto, że oświeceniowa teza

\footnotetext{
24 M. Zioło, Modlitwy wiecznego poniedziałku, Poznań 2016, s. 25.

25 E. Said, Orientalizm, przeł. M. Wyrwas-Wiśniewska, Poznań 2005, s. 163.
} 
o naturalnym związku postępu i sekularyzacji nie jest oczywista. Tropiąc motywowaną religijnie przemoc i krytykując brak tolerancji przedstawicieli poszczególnych religii, nie warto zamykać się szczelnie na inspiracje płynące $\mathrm{z}$ tradycji religijnych.

W związku z tym chciałbym zamknąć ten tekst kolejnym cytatem z książki Michała Zioły, który opisuje innego Christiana żyjącego i piszącego w Algierii mniej więcej w tym samym czasie. Mam na myśli Christiana de Chergé, przeora wspólnoty trapistów z Tibhirine, porwanych i zamordowanych przez islamskich terrorystów w 1996 roku. Tak o jego spotkaniu $\mathrm{z}$ islamem i muzułmanami pisze Zioło:

[C]o silniejsze charaktery potrafią do realizacji swoich pomysłów zatrudnić całą wspólnotę. Dobrym tego przykładem jest osoba przeora Tibhirine ojca Christiana, który przez całe życie mozolnie „urealniał swój idealizm” dialogu, ucząc się w bólu stosować te samy miary wobec atrakcyjnych dla niego kulturowo i intelektualnie muzułmanów i mniej atrakcyjnych i przewidywalnych w opiniach zakonnych współbraci, co oczywiście ważyło na jakości spotkań z tymi pierwszymi. Nie był sam w tych zmaganiach, bo towarzyszyła mu Reguła św. Benedykta, która nakazuje szanować wszystkich ludzi i bardzo nowocześnie posługuje się instrumentami owocnego dialogu - między innymi zasadą prawdy w spotkaniu: nie bój się zranić i być zranionym, przedstawiając swoje racje - to oznaka, że siebie i innych traktujesz poważnie, że uważasz ich za dojrzałych intelektualnie ludzi i żadnego elementu twoich poglądów przed nimi nie ukrywasz ${ }^{26}$.

\section{Bibliografia}

Amir-Moezzi Mohammad Ali [red.] (2007), Dictionnaire du Coran, Paris: Robert Laffont.

Arkoun Mohammed (2016), Lectures du Coran, Paris: Albin Michel.

Auerbach Erich (2006), Blizna Odyseusza, w: E. Auerbach, Mimesis. Rzeczywistość przedstawiona w literaturze Zachodu, przeł. Z. Żabicki, Warszawa: Prószyński i S-ka.

Bobako Monika (2017), Islamofobia jako technologia władzy. Studium z antropologii politycznej, Kraków: Universitas.

Chebel Malek (2011), Manifeste pour un islam des Lumières, Paris: Librairie Arthème Fayard.

Chmielewska Joanna (1993), Skarby, Warszawa: INTERART.

Chrisitan Michał (2007), Muzutmanie, islam i ja. Wspomnienia kooperanta z Algierii, b.m.w.

26 M. Zioło, Modlitwy wiecznego poniedziałku, s. 200. 
Corbin Henry (2009), Historia filozofii muzłmańskiej, przeł. K. Pachniak, Warszawa: Dialog.

Danecki Janusz (1997), Kultura islamu. Stownik, Warszawa: Wydawnictwa Szkolne i Pedagogiczne.

Danecki Janusz (2015), Arabowie, Warszawa: Państwowy Instytut Wydawniczy.

Kasznik-Christian Aleksandra (2006), Algieria, Łódź: Trio.

Khadra Yasmina (2001), L'écrivain, Paris: Julliard.

Koran (2016), przeł. J. Bielawski, Warszawa: Państwowy Instytut Wydawniczy. Meddeb Abdelwahab (2015), Instants soufis, Paris: Albin Michel.

Pawuła Andrzej (2018), Algierskie reminiscencje, Poznań: Bogucki Wydawnictwo Naukowe.

Said Edward (2005), Orientalizm, przeł. Monika Wyrwas-Wiśniewska, Poznań: Zysk i S-ka.

Troński Bronisław (1981), Nasi w Algierii, „Dziennik Łódzki”, 13-15.11.1981, s. 6.

Troński Bronisław (1984), Algierskie osobliwości, Poznań: Krajowa Agencja Wydawnicza.

Youssef Olfa (2007), Le Coran au risque de la psychanalyse, Paris: Albin Michel.

Youssef Olfa (2016), Sept controverses en islam. Parlons-en!, Tunis: Elyzad.

Zioło Michał (2016), Modlitwy wiecznego poniedziałku, Poznań: Wydawnictwo W drodze.

\title{
Prepare to Fight the Muhammad's Hordes, or Mr Michał's Algerian Case
}

\begin{abstract}
The article interprets the book Muzutmanie, islam i ja [Muslims, Islam and Me] by Michał Christian, which is an account of his stay in Algeria, where he worked as a specialist in the repair of construction machinery in the late eighties. While the main reason for Christian's trip was the desire to join his wife - Aleksandra Kasznik-Christian, history professor and scholar working in North Africa - the main impulse to write the account came from the September 11 attacks and Oriana Fallaci's books. The article aims to deconstruct the Orientalist preconceptions underlying Christian's vision of Islam and relations with Muslims.
\end{abstract}

Keywords: Quran, Algeria, Orientalism, islamophobia, Polish workers in Africa 